\title{
Differential effects of various soy isoflavone dietary supplements (nutraceuticals) on bacterial growth and human fibroblast viability
}

\author{
Karolina Pierzynowska1 ${ }^{凶}$, Agata Rzeszótko', Aleksandra Blendowska1, Ewa Wieczerzak², \\ Sylwia Rodziewicz-Motowidło², Ewa Piotrowska' and Grzegorz Węgrzyn'
}

1Department of Molecular Biology, Faculty of Biology, University of Gdańsk, Gdańsk, Poland; 2Faculty of Chemistry, University of Gdańsk, Gdańsk, Poland

Flavonoids, polyphenolic compounds present in many food products, affect growth of different bacterial species when tested as purified or synthetic substances. They can also influence gene expression in human cells, like fibroblasts. Here, we asked if soy isoflavone extracts, commonly used in many products sold as anti-menopausal dietary supplements, influence bacterial growth similarly to a synthetic isoflavone, genistein. Four commercially available products were tested in amounts corresponding to genistein concentrations causing inhibition of growth of Vibrio harveyi (a model bacterium sensitive to this isoflavone) and Escherichia coli (a model bacterium resistant to genistein). Differential effects of various extracts on $V$. harveyi and $E$. coli growth, from stimulation, to no changes, to inhibition, were observed. Moreover, contrary to genistein, the tested extracts caused a decrease (to different extent) in viability of human dermal fibroblasts. These results indicate that effects of various soy isoflavone extracts on bacterial growth and viability of human cells are different, despite similar declared composition of the commercially available products.

Key words: genistein, soy isoflavone extracts, anti-menopausal dietary supplements, bacterial growth, viability of human cells

Received: 30 March, 2018; revised: 16 April, 2018; accepted: 23 April, 2018; available on-line: 22 May, 2018

e-mail: karolina.pierzynowska@biol.ug.edu.pl

Abbreviations: DMSO, dimethyl sulfoxide; ELSD, evaporative light scattering detector; ESI, electrospray ionization; HDFa, human dermal fibroblasts - adult; MALDI-TOF, matrix assisted laser desorption/ionization - time of flight; MS, mass spectrometry; MTT, 3-(4,5-dimethylthiazol-2-yl)-2,5-diphenyltetrazolium bromide; UPLC, ultra performance liquid chromatography; TFA, trifluoroacetic acid

\section{INTRODUCTION}

Flavonoids are polyphenolic compounds present in many food products, including vegetables, fruits, tea and others (Chen et al., 2018). They are known as molecules of various biological activities (Mierziak et al., 2014; Mouradov \& Spangenberg, 2014). Among these activities, some have been recognized as beneficial for human health, and particularly the following features were reported: antioxidative properties, implication in coronary heart disease prevention, hepatoprotective, anti-inflammatory, and anticancer functions, as well as antiviral and antimicrobial actions (Kumar \& Pandey, 2013). Experimental studies indicated that flavonoids, especially isoflavones, can be also considered as drugs for some genetic diseases, particularly cystic fibrosis, mucopolysaccharidosis (reviewed in Wegrzyn, 2012; Wegrzyn et al., 2010), and Huntington's disease (Pierzynowska et al., 2018).

It was previously demonstrated that certain flavonoids have antibacterial activities which may result from inhibition of synthesis of macromolecules (U1anowska et al., 2006). Recent reports indicated that flavonoids can significantly influence human intestinal microbiota by inhibiting growth of certain bacterial species (Coppo \& Marchese, 2014; Xie et al., 2015). This is also true for dietary flavonoids and those present in food supplements or nutraceuticals (Marín et al., 2015).

One of the most popular groups of dietary supplements and nutraceuticals are soy isoflavones (D'Adamo \& Sahin, 2014). Isoflavone-rich soy extracts are commonly used products recommended against menopausal symptoms (Franco et al., 2016). On the other hand, isoflavones are one of the strongest antimicrobial agents among flavonoids, with genistein giving the most pronounced results (Ulanowska et al., 2006; Ulanowska et al., 2007). Therefore, the aim of this work was to test effects of commercially available dietary supplements/nutraceuticals containing soy isoflavone extracts (rather than purified isoflavones or their mixtures with precisely defined content) on model bacterial species. We asked how these commonly available dietary supplements and nutraceuticals might influence growth of bacteria. As models, the most sensitive to isoflavones - Vibrio harveyi, and the most resistant to these compounds - Escherichia coli, bacterial species (as determined previously by Ulanowska et al., 2007), were chosen. Moreover, effects of these extracts on viability of human cells (dermal fibroblasts) were tested. This type of cells was chosen since it was demonstrated that isoflavones can cause changes in expression of many genes in human fibroblasts, including those involved in glycosaminoglycan metabolism and lysosome biogenesis (Moskot et al., 2015a), cell cycle and DNA replication (Moskot et al., 2015b), proliferation and migration (Kim et al., 2015; Moskot et al., 2016). These studies were also substantiated by the fact that previous reports indicated that various commercially available soy extracts differ considerably in the actual amounts of isoflavones relative to those declared by manufacturers (Setchell et al., 2001; Chua et al., 2004; Piotrowska et al., 2010). Therefore, we assumed that testing biological activities of these products is of particular interest. Our results indicated different effects of various soy isoflavone 


\section{Table 1. Compositions of tested extracts}

\begin{tabular}{|c|c|}
\hline Extract no. & Composition (amount per tablet) \\
\hline Extract 1 & $\begin{array}{l}\text { Soy concentrate }(125 \mathrm{mg}) \text { including soy isoflavones }(50 \mathrm{mg}) \text {, calcium }(500 \mathrm{mg}) \text {, vit. D3 }(5 \mathrm{mg}) \text {, thiamine }(1.4 \mathrm{mg}) \text {, ribofla- } \\
\text { vin }(1.6 \mathrm{mg}) \text {, vit. B6 }(2 \mathrm{mg}) \text {, vit. B12 }(3 \mathrm{mg}) \text {, biotin }(150 \mathrm{mg}) \text {, folic acid }(150 \mathrm{mg})\end{array}$ \\
\hline Extract 2 & $\begin{array}{l}\text { Soy isoflavones }(50 \mathrm{mg}) \text {, extract from cone hops, extract from flax seeds }(10 \mathrm{mg}) \text {, calcium }(400 \mathrm{mg}) \text {, vit. E }(12 \mathrm{mg}) \text {, vit. } \\
\text { D3 (5 mg), vit. B6 }(1.4 \mathrm{mg}) \text {, folic acid }(200 \mathrm{mg}) \text {, calcium carbonate (a.n.s.), cellulose (a.n.s.), titanium dioxide (a.n.s.), bee } \\
\text { wax (a.n.s.), Carnauba wax (a.n.s.) }\end{array}$ \\
\hline Extract 3 & $\begin{array}{l}\text { Soy concentrate ( } 350 \mathrm{mg} \text { ) including soy isoflavones }(35 \mathrm{mg} \text { ), gelatin (a.n.s.), magnesium stearate (a.n.s.), titanium dioxi- } \\
\text { de (a.n.s.) }\end{array}$ \\
\hline Extract 4 & $\begin{array}{l}\text { Soy concentrate }(100 \mathrm{mg}) \text { including soy isoflavones }(26 \mathrm{mg}) \text {, microcrystal cellulose (a.n.s.), magnesium stearate (a.n.s.), } \\
\text { talc (a.n.s.), glycerol (a.n.s.) }\end{array}$ \\
\hline
\end{tabular}

Compositions are as provided by manufacturers; a.n.s., amount not specified by manufacturer

extracts on bacterial growth and human fibroblast viability, highlighting the problem of different quality of certain dietary supplements and nutraceuticals sold over-the-counter in vast majority of, if not all, countries.

\section{MATERIALS AND METHODS}

Bacterial strains and growth conditions. Laboratory strains of $V$. harveyi BB7 (Belas et al., 1982) and $E$. coli MG1655 Jensen, (1993) were used. Bacteria were cultured in nutrient media, either BOSS (1\% peptone, $0.3 \%$ beef extract, $0.1 \%$ glycerol, $3 \% \mathrm{NaCl}$ ) (Klein et al., 1998) (for $V$. harveyi cultivation) or LB (1\% tryptone, $0.5 \%$ yeast extract, $1 \% \mathrm{NaCl}$ ) (Sambrook et al., 1989) (for E. coli cultivation), at either $30^{\circ} \mathrm{C}$ (V. harveyi) or $37^{\circ} \mathrm{C}$ (E. coli) in shaking flasks.

Cell line and cell cultures. The cell line of human dermal fibroblasts - adult (the HDFa line, purchased from Thermo Fisher Scientific) was employed. Cells at early passages (according to Jędrak et al., 2017) were maintained in the DMEM medium containing 10\% fetal bovine serum and the penicillin-streptomycin mixture. Cells were cultured at $37^{\circ} \mathrm{C}$ in a humidified atmosphere with $5 \% \mathrm{CO}_{2}$.

Soy isoflavone extracts and synthetic genistein. Four commercially available products, registered as either medicines/nutraceuticals or dietary supplements, which should contain considerable amounts of soy isoflavones as declared by the manufacturers, were used. These products, referred to as extracts no. 1, 2, 3 and 4 in this report, were purchased commercially in Poland. The compositions of these extracts, according to information provided by manufacturers, are shown in Table 1. Synthetic genistein (manufactured as described previously by Grynkiewicz \& Szeja, 2016) was purchased from Pharmaceutical Research Institute in Warsaw (Poland).

Determination of soy isoflavones in dietary supplements by UPLC-ELSD method. A stock solution containing $1 \mathrm{mg}$ of genistein (from Pharmaceutical Research Institute, Poland) in $1 \mathrm{ml}$ DMSO was prepared and diluted to five different concentrations for obtaining calibration plots. Two tablets from one blister of each product were pulverized to powder (after removal of the coating, if necessary) and suspended in DMSO. The suspensions were placed in ultrasonic bath for $30 \mathrm{~min}$, then each of them was filtered through a $0.45 \mu \mathrm{m}$ membrane and analyzed by UPLC after dilution to suitable concentration. The chromatography was performed using Shimadzu NexeraX2 system. Compounds were separated on a $100 \times 2.1 \mathrm{~mm}, 2.6 \mu \mathrm{m}, \mathrm{C} 8$ Kinetex column using $0.1 \%$ aqueous TFA (solvent $\mathrm{A}$ ) and $80 \%$ acetonitrile $+0.1 \%$ TFA (solvent B) as a mobile phase with a linear gradient 0-100\% B for 15 min. Shimadzu ELSD-LT II detector was connected to this LC system. Purified nitrogen was used as a nebulizing gas. The drift-tube temperature and gain of the detector were $40^{\circ} \mathrm{C}$ and 9 , respectively.

To prepare calibration plots, five standard working solutions containing different concentrations of genistein were injected in triplicate. Integrated peak area (Y) was plotted against the amount of the substance in each standard sample $(\mathrm{X}, \mu \mathrm{g})$. Calibration plots were constructed directly on the basis of linear regression analysis. As the intensity of the scattered light is a function of the mass of the scattering particles, the approximate amount of isoflavones (daidzein, genistein) and their glycosides (daidzin, genistin), in each dietary supplement was calculated from the calibration plot obtained for genistein. The obtained data are presented in Table 2. The identity of each compound was confirmed by ESI-MS using Shimadzu LC MS-IT-TOF apparatus (exemplary data for Extract 4 are presented in Table 3).

Raw plots of UPLC and MALDI-TOF MS are presented in Supplementary Material (Supplementary Figs. S1-S4, and S5-S8, respectively at www.actabp.pl).

Monitoring of bacterial growth. Bacteria were cultured overnight under conditions described above. Following dilution of the culture with fresh medium, at the $\mathrm{v} / \mathrm{v}$ ratio $1: 100$, bacteria were cultured under the same conditions, and $\mathrm{A}_{595}$ was measured every $15 \mathrm{~min}$. The extracts were purchased in the form of tablets, which were crushed and dissolved in DMSO. Such extracts were

Table 2. The approximate amount (in $\mathrm{mg}$ ) of daidzin, genistin, daidzein and genistein in one tablet of each dietary supplement examined.

The values were calculated from results of 3-6 assays and are presented as mean value \pm S.D.

\begin{tabular}{lllll}
\hline Extract & Daidzin $(\mathrm{mg})$ & Genistin $(\mathrm{mg})$ & Daidzein $(\mathrm{mg})$ & Genistein $(\mathrm{mg})$ \\
\hline Extract 1 & $65.28 \pm 3.15$ & $63.69 \pm 4.27$ & $0.14 \pm 0.06$ & $0.26 \pm 0.17$ \\
\hdashline Extract 2 & $24.88 \pm 5.05$ & $2.42 \pm 0.43$ & $0.22 \pm 0.09$ & 0 \\
\hline Extract 3 & $3.20 \pm 1.47$ & $13.77 \pm 2.12$ & $22.68 \pm 6.62$ & 0 \\
\hline Extract 4 & $13.08 \pm 2.00$ & $51.83 \pm 5.51$ & $1.14 \pm 0.50$ & $0.75 \pm 0.43$ \\
\hline
\end{tabular}


Table 3. Soy isoflavones in Extract 4 tablet: MS Data and Retention Times during UPLC-ELSD analysis.

\begin{tabular}{lllll}
\hline Peak no. & Compound & $\mathrm{MW}(\mathrm{g} / \mathrm{mol})$ & $(\mathrm{M}+\mathrm{H})^{+}(\mathrm{m} / \mathrm{z})$ & $\mathrm{R}_{\mathrm{T}}(\mathrm{min})$ \\
\hline 1 & Daidzin & 416.4 & 417 & 3.4 \\
\hline 2 & Genistin & 432.4 & 433 & 4.1 \\
\hdashline 3 & Daidzein & 254.2 & 255 & 5.2 \\
\hline 4 & Genistein & 270.2 & 271 & 6.2 \\
\hline
\end{tabular}

added to the bacterial cultures at the early exponential phase of growth $\left(\mathrm{A}_{505}=0.1\right)$, to final concentrations corresponding to 30,60 and $100 \mu \mathrm{M}$ isoflavones (included in each extract). In control experiments, either DMSO (final concentration $0.1 \%$; negative control) or genistein (final concentration 30, 60 or $100 \mu \mathrm{M}$; positive control) were added. Growth curves were analyzed, and bacterial generation times were calculated on the basis of $\mathrm{A}_{595}$ values at the exponential phase of bacterial culture growth.

MTT cell viability assay. The assay was performed according to Wasilewski and coworkers (Wasilewski et al., 2017), with some modifications. Briefly, $4 \times 10^{3} \mathrm{HDFa}$ cells were passaged in each well of a 96-well plate, and allowed to attach overnight. Cells were then treated with DMSO (final concentration $0.1 \%$; negative control), or 30, 60 or $100 \mu \mathrm{M}$ genistein (positive control), or extracts (at final concentrations corresponding to 30,60 or $100 \mu \mathrm{M}$ isoflavones, included in each extract) at $37^{\circ} \mathrm{C}$. After 24 or $48 \mathrm{~h}$ incubation, $25 \mu \mathrm{l}$ of MTT solution $(4 \mathrm{mg} / \mathrm{ml})$ was added to each well. Following $3 \mathrm{~h}$ incubation at $37^{\circ} \mathrm{C}$, formazan crystals, formed in living cells, were dissolved in $100 \mu \mathrm{l}$ of DMSO. Absorbance was measured at $570 \mathrm{~nm}$ and 620 $\mathrm{nm}$ (reference wavelength) in a Victor $^{3}$ microplate reader.

Statistical analyses. One-way ANOVA test was used for testing statistical significance of obtained results versus control (no added compound). Two-way ANOVA test was employed to assess correlation between the tested extract
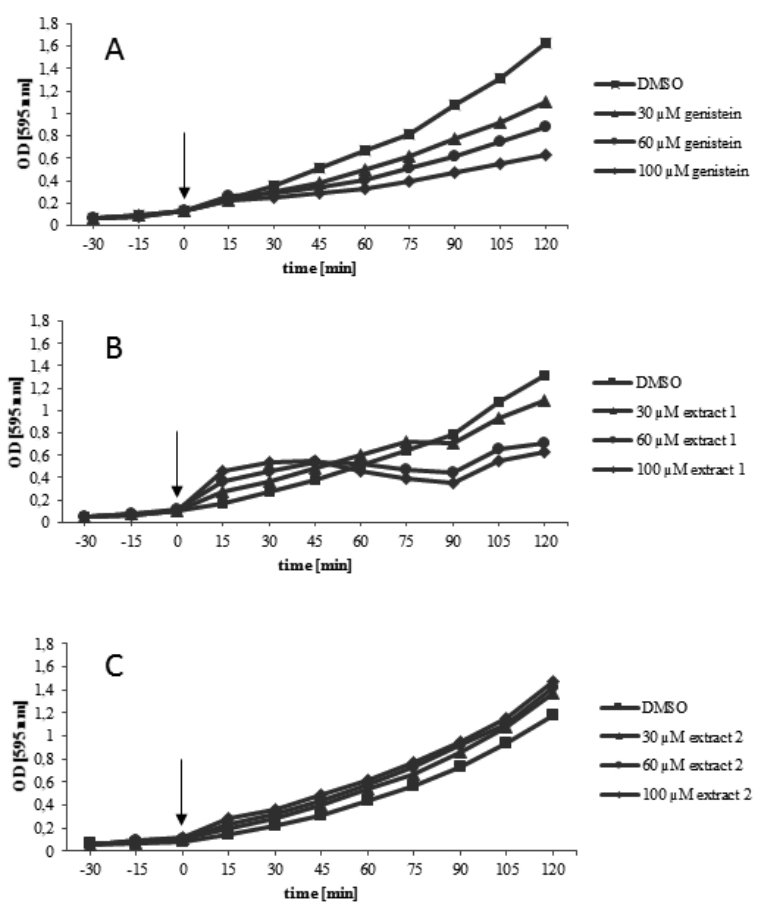

and isoflavone concentration. In both tests, differences were considered statistically significant when $p<0.05$.

\section{RESULTS AND DISCUSSION}

It was reported previously that determination of growth rate, particularly generation time, in a liquid culture can be considered as an optimal method for estimation of effects of flavonoids on bacteria (Ulanowska et al., 2007). This is because methods based on diffusion are problematic due to low rate of diffusion of flavonoids, and other factors (like inoculum size, disk size, incubation period) may influence the results (Cushnie \& Lamb, 2005). Therefore, to determine if the tested soy isoflavone extracts influence growth of two bacterial species, $V$. harveyi (previously demonstrated to be sensitive to genistein by Ulanowska et al., 2006; Ulanowska et al., 2007), and E. coli (previously demonstrated to be resistant to genistein by Ulanowska et al., 2006; Ulanowska et al., 2007), we monitored growth of bacterial liquid cultures and calculated generation times in the presence and absence of isoflavone(s).

Representative growth curves are presented in Fig. 1 (for $V$. harveyi) and Fig. 2 (for E. coli), and calculated generation times are shown in Table 4 (for $V$. harveyi) and Table 5 (for E. coli). Generation times were calculated for two time periods, first, $0-30 \mathrm{~min}$, where 0 is
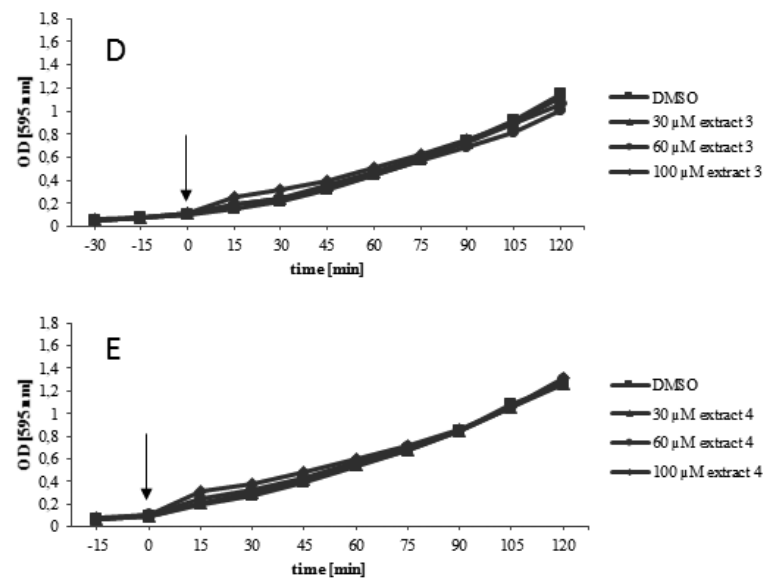

Figure 1. Effects of genistein and different extracts on V. harveyi BB7 growth. Bacteria were cultured in the BOSS medium at $30^{\circ} \mathrm{C}$, and different compounds were added at time 0 to indicated concentrations. Representative growth curves are shown. 

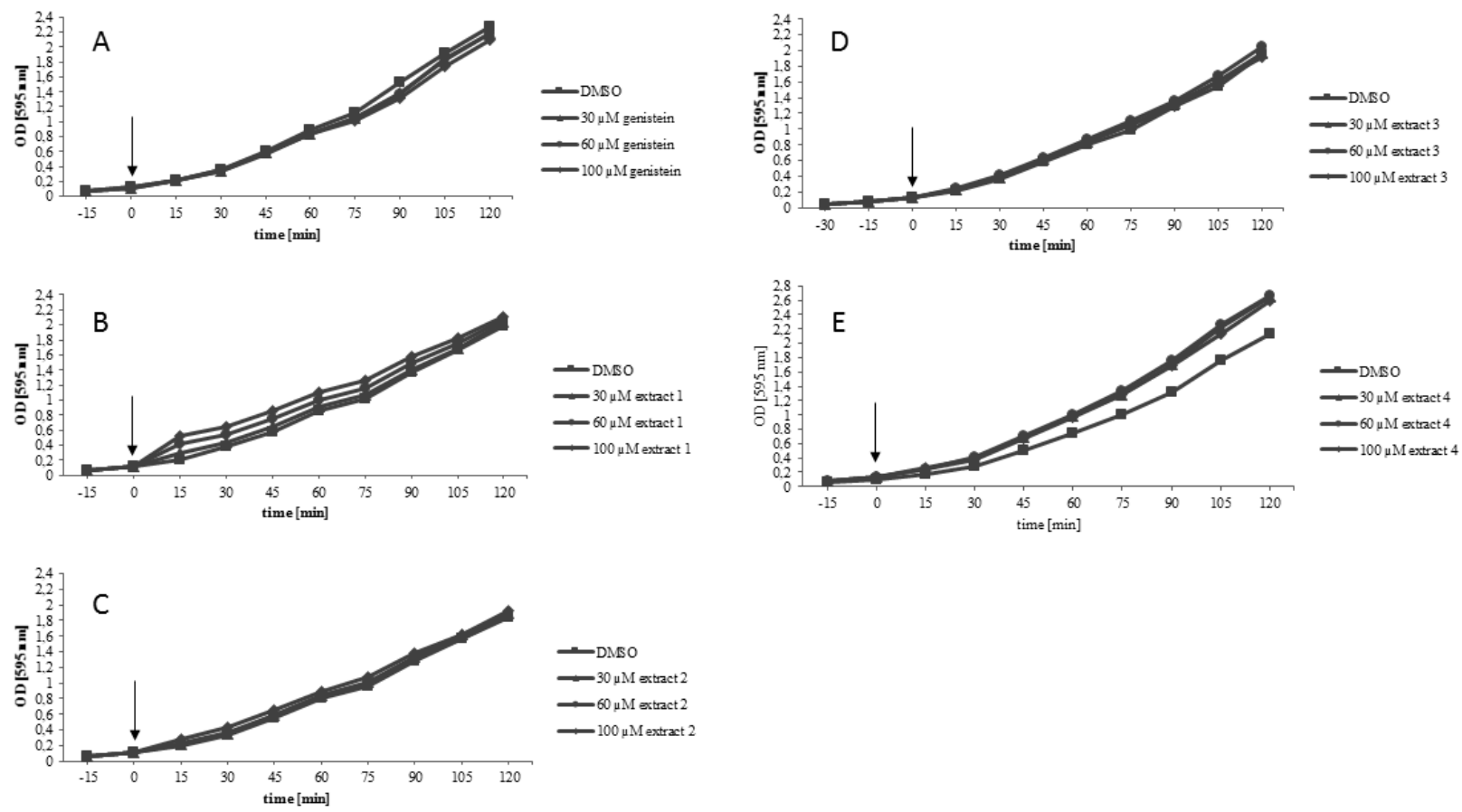

Figure 2. Effects of genistein and different extracts on E. coli MG1655 growth.

Bacteria were cultured in the LB medium at $37^{\circ} \mathrm{C}$, and different compounds were added at time 0 to indicated concentrations. Representative growth curves are shown.

the time of the tested compund or extract addition), and second, between 60 and $120 \mathrm{~min}$ after tested compound or extract addition (i.e. 60-120 min). As expected, genistein impaired growth of $V$. harveyi in both time periods, while it had no significant effect on E. coli. However, differential effects were observed for various soy isoflavone extracts. Extract 1 stimulated $V$. harveyi growth shortly after its addition to the culture (0-30 min), while strongly inhibiting the growth later on. Similar, though less pronounced effects were observed for extract 3. On the other hand, extract 2 caused only some stimulation of $V$. barveyi growth shortly after its addition to the culture,
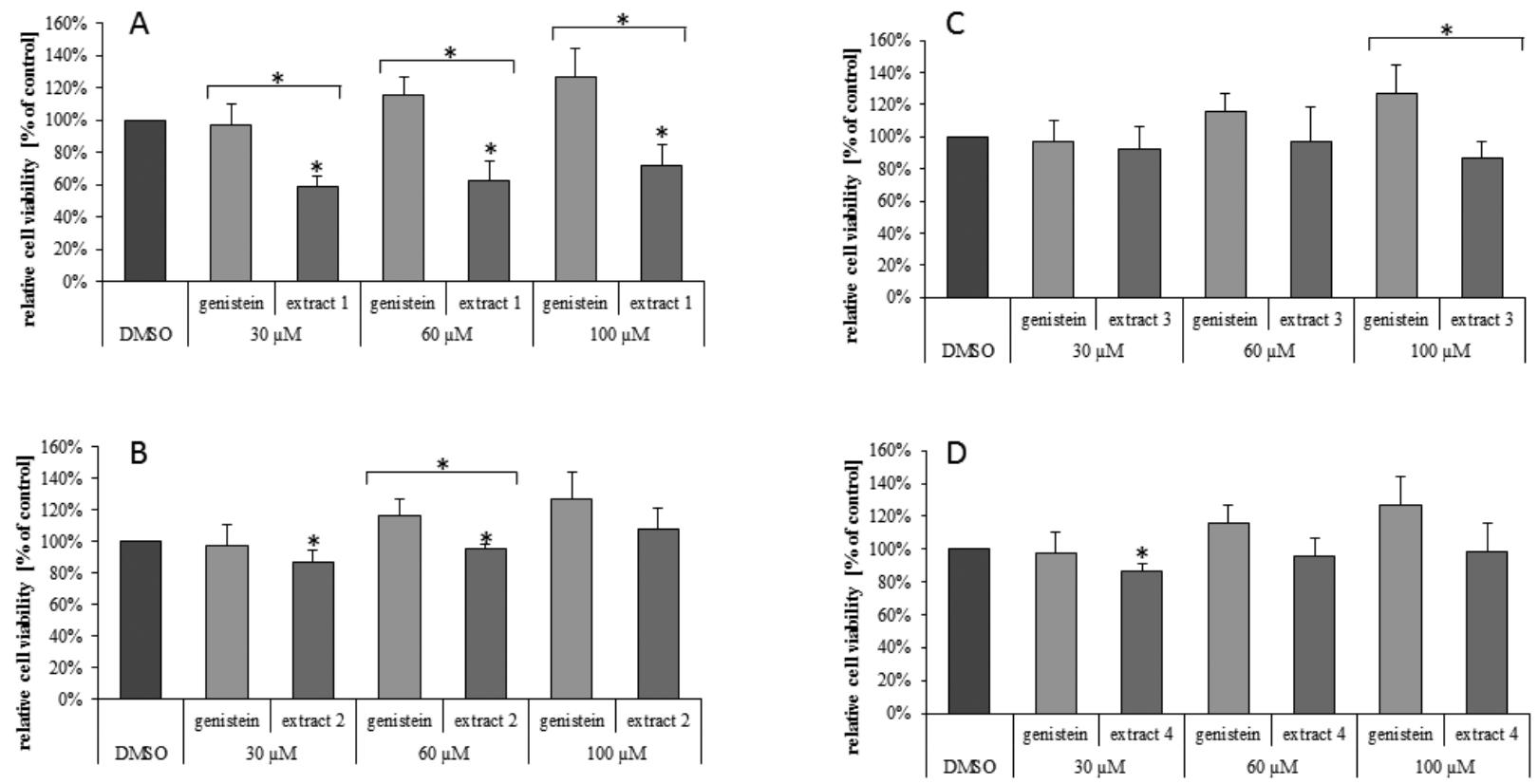

Figure 3. Effects of genistein and different extracts on human cells (the HDFa line) after $24 \mathrm{~h}$ incubation.

Either genistein or different extracts were added to the culture medium to indicated final concentrations. DMSO was added in control experiments to $0.1 \%$ final concentration. The MTT test was performed. Mean values from 3 independent experiments are shown with error bars indicating S.D. Statistically significant differences $(p<0.05$ in one-way ANOVA) are marked with asterisks either above particular columns (differences vs. DMSO control) or above brackets (differences vs. genistein). 
Table 4. Generation times of $V$. harveyi cultures treated with different compounds

\begin{tabular}{|c|c|c|c|c|c|c|}
\hline Sample & $\begin{array}{l}\text { Generation time } \\
\text { (min) } \\
(0-30 \mathrm{~min})\end{array}$ & $\begin{array}{l}p \text { value: sample } \\
\text { vs. DMSO }\end{array}$ & $\begin{array}{l}p \text { value: sample } \\
\text { vs. genistein }\end{array}$ & $\begin{array}{l}\text { Generation time } \\
\text { (min) } \\
(60-120 \mathrm{~min})\end{array}$ & $\begin{array}{l}p \text { value: sample } \\
\text { vs. DMSO }\end{array}$ & $\begin{array}{l}p \text { value: sample } \\
\text { vs. genistein }\end{array}$ \\
\hline \multicolumn{7}{|l|}{ Genistein } \\
\hline $\begin{array}{l}0 \mu \mathrm{M} \\
\text { (DMSO) }\end{array}$ & $24 \pm 2$ & $\mathrm{~N} / \mathrm{A}$ & $\mathrm{N} / \mathrm{A}$ & $42 \pm 3$ & $\mathrm{~N} / \mathrm{A}$ & N/A \\
\hline $30 \mu \mathrm{M}$ & $26 \pm 1$ & $>0.05$ & $\mathrm{~N} / \mathrm{A}$ & $50 \pm 3$ & $<0.05^{*}$ & N/A \\
\hline $60 \mu \mathrm{M}$ & $29 \pm 5$ & $<0.05^{*}$ & $\mathrm{~N} / \mathrm{A}$ & $53 \pm 3$ & $<0.05^{*}$ & $\mathrm{~N} / \mathrm{A}$ \\
\hline $100 \mu \mathrm{M}$ & $34 \pm 4$ & $<0.05^{*}$ & $\mathrm{~N} / \mathrm{A}$ & $60 \pm 3$ & $<0.05^{*}$ & $\mathrm{~N} / \mathrm{A}$ \\
\hline \multicolumn{7}{|l|}{ Extract 1} \\
\hline $\begin{array}{l}0 \mu \mathrm{M} \\
\text { (DMSO) }\end{array}$ & $24 \pm 1$ & $\mathrm{~N} / \mathrm{A}$ & $\mathrm{N} / \mathrm{A}$ & $42 \pm 2$ & $\mathrm{~N} / \mathrm{A}$ & N/A \\
\hline $30 \mu \mathrm{M}$ & $18 \pm 1$ & $<0.05^{*}$ & $<0.05^{*}$ & $60 \pm 11$ & $<0.05^{*}$ & $>0.05$ \\
\hline $60 \mu \mathrm{M}$ & $15 \pm 0$ & $<0.05^{*}$ & $<0.05^{*}$ & $109 \pm 36$ & $<0.05^{*}$ & $>0.05$ \\
\hline $100 \mu \mathrm{M}$ & $13 \pm 1$ & $<0.05^{*}$ & $<0.05^{*}$ & $133 \pm 52$ & $<0.05^{*}$ & $>0.05$ \\
\hline \multicolumn{7}{|l|}{ Extract 2} \\
\hline $\begin{array}{l}0 \mu \mathrm{M} \\
\text { (DMSO) }\end{array}$ & $22 \pm 0$ & $\mathrm{~N} / \mathrm{A}$ & $\mathrm{N} / \mathrm{A}$ & $42 \pm 5$ & N/A & $\mathrm{N} / \mathrm{A}$ \\
\hline $30 \mu \mathrm{M}$ & $21 \pm 2$ & $>0.05$ & $<0.05^{*}$ & $45 \pm 6$ & $>0.05$ & $>0.05$ \\
\hline $60 \mu \mathrm{M}$ & $20 \pm 1$ & $<0.05^{*}$ & $<0.05^{*}$ & $47 \pm 1$ & $>0.05$ & $<0.05^{*}$ \\
\hline $100 \mu \mathrm{M}$ & $19 \pm 2$ & $<0.05^{*}$ & $<0.05^{*}$ & $48 \pm 5$ & $>0.05$ & $<0.05^{*}$ \\
\hline \multicolumn{7}{|l|}{ Extract 3} \\
\hline $\begin{array}{l}0 \mu \mathrm{M} \\
\text { (DMSO) }\end{array}$ & $30 \pm 2$ & $\mathrm{~N} / \mathrm{A}$ & N/A & $44 \pm 3$ & N/A & $\mathrm{N} / \mathrm{A}$ \\
\hline $30 \mu \mathrm{M}$ & $29 \pm 2$ & $>0.05$ & $>0.05$ & $49 \pm 3$ & $<0.05^{*}$ & $>0.05$ \\
\hline $60 \mu \mathrm{M}$ & $25 \pm 2$ & $<0.05^{*}$ & $>0.05$ & $52 \pm 3$ & $<0.05^{*}$ & $>0.05$ \\
\hline $100 \mu \mathrm{M}$ & $20 \pm 3$ & $<0.05^{*}$ & $<0.05^{*}$ & $57 \pm 2$ & $<0.05^{*}$ & $>0.05$ \\
\hline \multicolumn{7}{|l|}{ Extract 4} \\
\hline $\begin{array}{l}0 \mu \mathrm{M} \\
\text { (DMSO) }\end{array}$ & $21 \pm 2$ & $\mathrm{~N} / \mathrm{A}$ & $\mathrm{N} / \mathrm{A}$ & $46 \pm 3$ & $\mathrm{~N} / \mathrm{A}$ & $\mathrm{N} / \mathrm{A}$ \\
\hline $30 \mu \mathrm{M}$ & $21 \pm 3$ & $>0.05$ & $<0.05^{*}$ & $48 \pm 2$ & $>0.05$ & $>0.05$ \\
\hline $60 \mu \mathrm{M}$ & $19 \pm 2$ & $>0.05$ & $>0.05$ & $49 \pm 2$ & $>0.05$ & $<0.05^{*}$ \\
\hline $100 \mu \mathrm{M}$ & $17 \pm 2$ & $>0.05$ & $<0.05^{*}$ & $52 \pm 1$ & $<0.05^{*}$ & $<0.05^{*}$ \\
\hline
\end{tabular}

Generation times were calculated for two periods: between 0 and $30 \mathrm{~min}$ after addition of genistein or extract (or $0.1 \%$ DMSO in control experiments), and between 60 and 120 min after addition of genistein or extract (or $0.1 \%$ DMSO in control experiments). Results are presented as mean values from at least 3 independent experiments \pm S.D. $p$ values were calculated using one-way ANOVA, statistically significant differences were assumed when $p<0.05$ (values marked with asterisks). N/A, not applicable.

and had no significant effect in the 60-120 min time interval. Extract 4 revealed the weakest effect on $V$. harveyi growth, as the only considerable change in growth rate was noted at the highest tested concentration between 60 and $120 \mathrm{~min}$ after culture supplementation.

Although genistein did not influence growth of E. coli, extracts 1 and 2 caused a significant decrease in the generation time immediately after their addition to the culture. Moreover, addition of extract 3 at the highest concentration resulted in a longer generation time of the E. coli culture in the 60-120 min time interval.

Statistical analyses performed with the use of two-way ANOVA indicated that there is a significant correlation between the kind of extract and isoflavone concentration when measuring effects on bacterial growth, at both tested time periods $(p<0.05$ in each case). These analyses confirmed the conclusions presented in preceding paragraphs.
The results described above indicated that despite using the same concentrations of soy isoflavones present in various commercially available products, their effects on bacterial growth were different. These differences might arise from activities of other compounds (either identified molecules or unidentified substances from extracts or both) present in the products (see Table 1). Different extracts, investigated in this work, contain various additional compounds, including well-characterized molecules, like calcium, vit. D3, vit. E, thiamine, riboflavin, vit. B6, vit. B12, biotin, folic acid, cellulose, titanium dioxide, magnesium stearate, talc, and glycerol. In fact, some of them are known as stimulators of bacterial growth (e.g. vitamins, glycerol) while others might be suspected to inhibit it, particularly those included in poorly characterized extracts from cone hops and flax seeds, as well as bee wax and Carnauba wax. On the other hand, discrepancies between the declared (by manufacturers) and actual compositions of extracts were 
Table 5. Generation times of E. coli cultures treated with different compounds

\begin{tabular}{|c|c|c|c|c|c|c|}
\hline Sample & $\begin{array}{l}\text { Generation time } \\
\text { (min) } \\
(0-30 \mathrm{~min})\end{array}$ & $\begin{array}{l}p \text { value: sample } \\
\text { vs. DMSO }\end{array}$ & $\begin{array}{l}p \text { value: sample } \\
\text { vs. genistein }\end{array}$ & $\begin{array}{l}\text { Generation time } \\
\text { (min) } \\
(60-120 \mathrm{~min})\end{array}$ & $\begin{array}{l}p \text { value: sample } \\
\text { vs. DMSO }\end{array}$ & $\begin{array}{l}p \text { value: sample } \\
\text { vs. genistein }\end{array}$ \\
\hline \multicolumn{7}{|l|}{ Genistein } \\
\hline $\begin{array}{l}0 \mu \mathrm{M} \\
\text { (DMSO) }\end{array}$ & $22 \pm 3$ & $\mathrm{~N} / \mathrm{A}$ & $\mathrm{N} / \mathrm{A}$ & $41 \pm 4$ & $\mathrm{~N} / \mathrm{A}$ & $\mathrm{N} / \mathrm{A}$ \\
\hline $30 \mu \mathrm{M}$ & $21 \pm 4$ & $>0.05$ & $\mathrm{~N} / \mathrm{A}$ & $41 \pm 3$ & $>0.05$ & N/A \\
\hline $60 \mu \mathrm{M}$ & $19 \pm 2$ & $>0.05$ & $\mathrm{~N} / \mathrm{A}$ & $42 \pm 4$ & $>0.05$ & N/A \\
\hline $100 \mu \mathrm{M}$ & $20 \pm 3$ & $>0.05$ & N/A & $43 \pm 3$ & $>0.05$ & N/A \\
\hline \multicolumn{7}{|l|}{ Extract 1} \\
\hline $\begin{array}{l}0 \mu \mathrm{M} \\
\text { (DMSO) }\end{array}$ & $19 \pm 1$ & $\mathrm{~N} / \mathrm{A}$ & $\mathrm{N} / \mathrm{A}$ & $48 \pm 2$ & $\mathrm{~N} / \mathrm{A}$ & $\mathrm{N} / \mathrm{A}$ \\
\hline $30 \mu \mathrm{M}$ & $16 \pm 1$ & $<0.05^{*}$ & $<0.05^{* *}$ & $50 \pm 3$ & $>0.05$ & $<0.05^{*}$ \\
\hline $60 \mu \mathrm{M}$ & $14 \pm 1$ & $<0.05^{*}$ & $<0.05^{* *}$ & $53 \pm 5$ & $>0.05$ & $<0.05^{*}$ \\
\hline $100 \mu \mathrm{M}$ & $12 \pm 1$ & $<0.05^{*}$ & $<0.05^{* *}$ & $60 \pm 5$ & $>0.05$ & $<0.05^{*}$ \\
\hline \multicolumn{7}{|l|}{ Extract 2} \\
\hline $\begin{array}{l}0 \mu \mathrm{M} \\
\text { (DMSO) }\end{array}$ & $19 \pm 1$ & $\mathrm{~N} / \mathrm{A}$ & $\mathrm{N} / \mathrm{A}$ & $44 \pm 11$ & $\mathrm{~N} / \mathrm{A}$ & $\mathrm{N} / \mathrm{A}$ \\
\hline $30 \mu \mathrm{M}$ & $18 \pm 0$ & $<0.05^{* *}$ & $>0.05$ & $46 \pm 10$ & $>0.05$ & $>0.05$ \\
\hline $60 \mu \mathrm{M}$ & $17 \pm 1$ & $<0.05^{* *}$ & $>0.05$ & $47 \pm 10$ & $>0.05$ & $>0.05$ \\
\hline $100 \mu \mathrm{M}$ & $16 \pm 1$ & $<0.05^{* *}$ & $<0.05^{*}$ & $48 \pm 11$ & $>0.05$ & $>0.05$ \\
\hline \multicolumn{7}{|l|}{ Extract 3} \\
\hline $\begin{array}{l}0 \mu \mathrm{M} \\
\text { (DMSO) }\end{array}$ & $20 \pm 0$ & $\mathrm{~N} / \mathrm{A}$ & $\mathrm{N} / \mathrm{A}$ & $48 \pm 1$ & N/A & N/A \\
\hline $30 \mu \mathrm{M}$ & $20 \pm 1$ & $>0.05$ & $>0.05$ & $51 \pm 1$ & $>0.05$ & $>0.05$ \\
\hline $60 \mu \mathrm{M}$ & $19 \pm 1$ & $>0.05$ & $>0.05$ & $50 \pm 1$ & $>0.05$ & $<0.05^{*}$ \\
\hline $100 \mu \mathrm{M}$ & $19 \pm 1$ & $<0.05^{*}$ & $>0.05$ & $53 \pm 1$ & $<0.05^{*}$ & $<0.05^{*}$ \\
\hline \multicolumn{7}{|l|}{ Extract 4} \\
\hline $\begin{array}{l}0 \mu \mathrm{M} \\
\text { (DMSO) }\end{array}$ & $22 \pm 3$ & $\mathrm{~N} / \mathrm{A}$ & $\mathrm{N} / \mathrm{A}$ & $41 \pm 4$ & $\mathrm{~N} / \mathrm{A}$ & N/A \\
\hline $30 \mu \mathrm{M}$ & $19 \pm 3$ & $>0.05$ & $>0.05$ & $42 \pm 3$ & $>0.05$ & $>0.05$ \\
\hline $60 \mu \mathrm{M}$ & $18 \pm 1$ & $>0.05$ & $>0.05$ & $44 \pm 3$ & $>0.05$ & $>0.05$ \\
\hline $100 \mu \mathrm{M}$ & $19 \pm 1$ & $>0.05$ & $>0.05$ & $43 \pm 1$ & $>0.05$ & $>0.05$ \\
\hline
\end{tabular}

Generation times were calculated for two periods: between 0 and $30 \mathrm{~min}$ after addition of genistein or extract (or $0.1 \%$ DMSO in control experiments), and between 60 and 120 min after addition of genistein or extract (or $0.1 \%$ DMSO in control experiments). Results are presented as mean values from at least 3 independent experiments \pm S.D. $p$ values were calculated using one-way ANOVA, statistically significant differences were assumed when $p<0.05$ (values marked with asterisks).

reported previously for other products (Piotrowska et al., 2010; Andres et al., 2015). Irrespective of the cause of this phenomenon, differential effects of tested extracts on bacterial growth are evident. This might be especially important in the light of recent studies which demonstrated that flavonoids can significantly influence the human gut microbiome Coppo \& Marchese, 2014; Marín et al., 2015).

Other differential biological effects of various soy isoflavone extracts were reported previously, when synthesis of glycosaminoglycans was tested in human fibroblasts (Piotrowska et al., 2010). Therefore, we have also tested the effects of investigated extracts on viability of human cells (the HDFa cell line). By using the MTT test, we estimated the fraction of viable cells after different times of treatment with the tested extracts at different concentrations.

In control experiments, according to previously published results (Kloska et al., 2012), we found no signifi- cant cytotoxic effects of synthetic genistein (Figs. 3 and 4). Although genistein is a known inhibitor of tyrosine kinases (Peterson, 1995), it can also stimulate activities of various transcription factors, like TFEB (Moskot et al., 2014) affecting expression of many genes, and it was demonstrated that isoflavones may promote human dermal fibroblast proliferation and migration via TGF- $\beta$ signaling (Kim et al., 2015). Thus, inhibition of tyrosine kinases' activities might be compensated, at least at certain genistein concentrations. However, $24 \mathrm{~h}$ incubation with the tested extracts was enough to decrease viability of human fibroblasts by extract 1 (at all tested concentrations) and extracts 2 and 3 at certain concentrations (Fig. 3). Even more pronounced cytotoxic effects were observed after $48 \mathrm{~h}$ incubation, when viability of human cells was significantly decreased, particularly in the presence of extracts 1 and 2, and to some extent in the presence of extracts 3 and 4 (Fig. 4). 

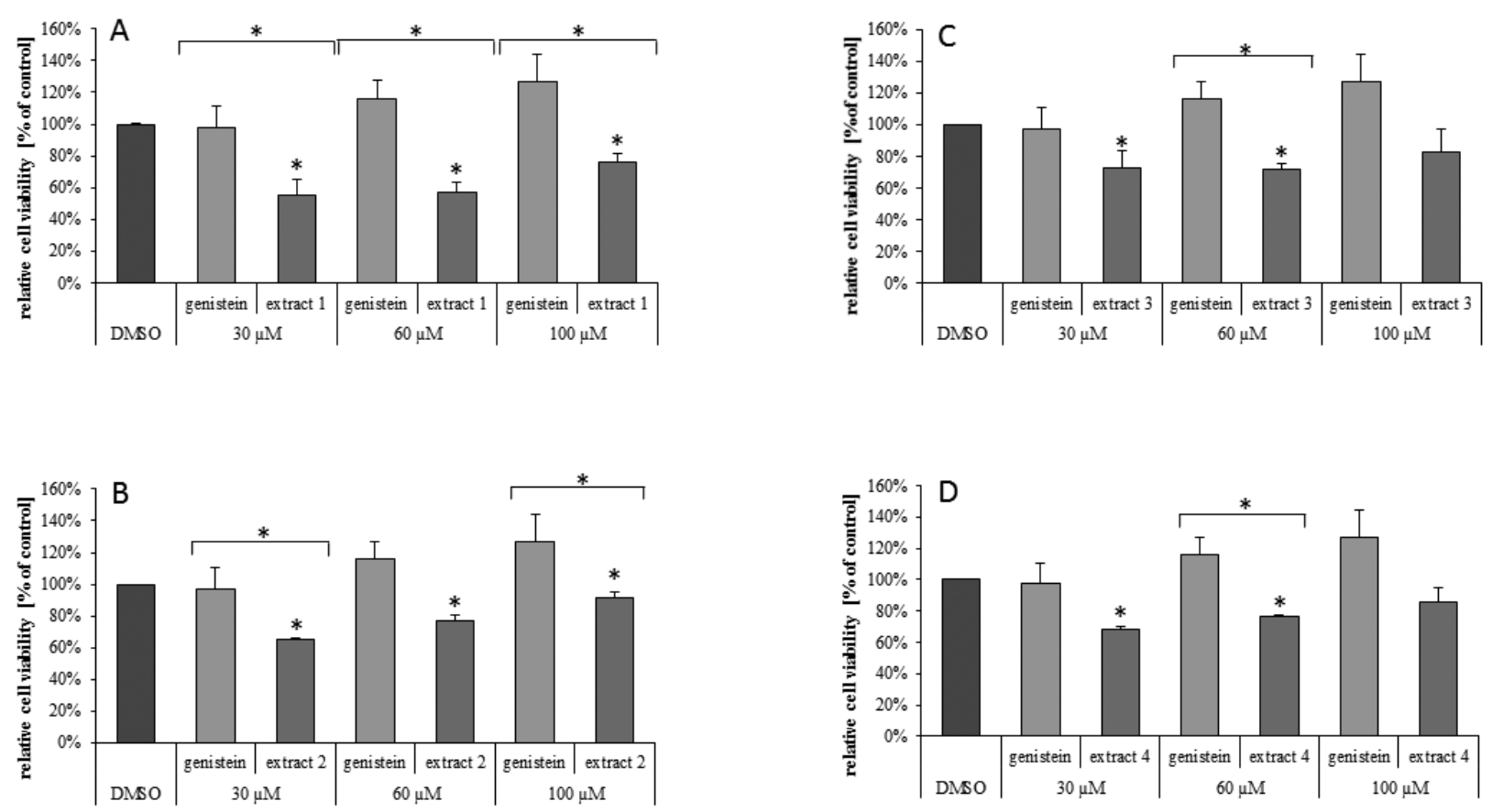

Figure 4. Effects of genistein and different extracts on human cells (the HDFa line) after $48 \mathrm{~h}$ incubation.

Either genistein or different extracts were added to the culture medium to indicated final concentrations. DMSO was added in control experiments to $0.1 \%$ final concentration. The MTT test was performed. Mean values from 3 independent experiments are shown with error bars indicating S.D. Statistically significant differences $(p<0.05$ in one-way ANOVA) are marked with asterisks either above particular columns (differences vs. DMSO control) or above brackets (differences vs. genistein).

These results indicated again that various soy isoflavone extracts exhibit different biological activities despite the same content of isoflavones declared by their manufacturers. This is true for effects on both, bacterial and human cells. Although synthetic genistein demonstrated a high level of safety both, in vitro (Kloska et al., 2012) and in vivo during clinical studies (Kim et al., 2013), as well as beneficial profile of antimicrobial effects (Ulanowska et al., 2007), confirmed in this study, some extracts revealed significant effects on E. coli growth, and their cytotoxicity to human fibroblasts was also detected. Since it was demonstrated that different flavonoids can shape the unique profile of gut microbiota (Huang et al., 2016), one might assume a potential influence of isoflavone-rich diet supplements or nutraceuticals on human intestinal flora. It is worth to mention that studies from different countries indicated huge variability in compositions of different soy isoflavone extracts. Setchell and coworkers (2001) analyzed 33 phytoestrogen supplements and extracts, derived from different countries (USA, the Netherlands, and UK) and found considerable differences in the isoflavone content from the one claimed by the manufacturers; in some products the differences were 5 to 10 -fold, and one product contained no detectable amount of isoflavones. The level of impurities was high in most of the products. Chua et al. (2004) found that among 13 commercially available extracts (purchased in the Washington State, USA), only 4 contained at least $90 \%$ of the isoflavone content claimed on the label. Moreover, in 2 products, impurities exceeded $40 \%$ of the total mass of the extract.

Piotrowska and coworkers (2010) analyzed 7 commercially available soy isoflavone extracts, and determined that amounts of isoflavones were similar to those declared by manufacturers in only 3 of them. Other products contained significantly less isoflavones than claimed on the label, while one contained a 200-fold lower level.
Considerable contaminations were detected in isoflavone-poor extracts.

Determination of isoflavone amounts in extracts investigated in this work, performed by using UPLCELSD and MS, indicated that the actual contents of these compounds also differ considerably from those declared by manufactures. According to commercial description of the products, the amounts of isoflavones per tablet were $50,50,35$, and $26 \mathrm{mg}$ in extracts $1,2,3$, and 4 , respectively, while the values estimated experimentally by us were approximately $130,27,30$, and $65 \mathrm{mg}$, respectively (when considering glycosides and aglycans together). Moreover, glycosides were highly predominant over aglycans which might influence biological activities of the extracts, beside actions of other compounds present in the tested products.

In conclusion, results presented in this report and the facts discussed above should be taken into account when the use of soy isoflavone extracts is considered, especially as local concentrations of the compounds included in a given tablet can reach high levels in the human intestine after oral administration of these nutraceuticals or dietary supplements.

\section{Authors' contributions}

$\mathrm{KP}$ designed experiments, performed most of experiments with human cell cultures, and analyzed results. AR performed experiments with bacterial cultures. $A B$ participated in experiments with human cell cultures. EW and SR-M performed chemical analyses of extracts. EP performed statistical analyses. GW supervised the project, participated in planning experiments and in analysis of results, and drafted the manuscript.

\section{Conflict of interest}

The authors declare no conflict of interest. 


\section{Acknowledgments}

The authors thank Krystyna Bogucka for technical assistance.

\section{Acknowledgements of Financial Support}

This work was supported by the University of Gdansk, Gdańsk, Poland (task grant no. 530-L140-D242-17$1 \mathrm{~A})$.

\section{REFERENCES}

Andres S, Hansen U, Niemann B, Palavinskas R, Lampen, A (2015) Determination of the isoflavonecomposition and estrogenic activity of commercial dietary supplements based on soy or red clover. Food Funct 6: 2017-2025. doi: 10.1039/c5fo00308c

Belas R, Mileham A, Cohn D, Hilmen M, Simon M, Silverman M (1982) Bacterial luminescence: isolation and expression of the luciferase genes from Vibrio harveyi. Science 218: 791-793. doi: 10.1126/ science. 10636771

Chen L, Teng H, Xie Z, Cao H, Cheang WS, Skalicka-Woźniak K, Georgiev MI, Xiao J (2018) Modifications of dietary flavonoids towards improved bioactivity: an update on structure-activity relationship. Crit Rev Food Sci Nutr 58: 513-527. https://doi.org/10.1080/1 0408398.2016.1196334

Chua R, Anderson K, Chen J, Hu M (2004) Quality, labeling accuracy, and cost comparison of purified soy isoflavonoid products. I Altern Complement Med 10: 1053-1060. doi: 10.1089/acm.2004.10.1053

Coppo E, Marchese A (2014) Antibacterial activity of polyphenols. Curr Pharm Biotechnol 15: 380-390. doi: 10.2174/1389201015041408 25121142

Cushnie TPT, Lamb AJ (2005) Antimicrobial activity of flavonoids. Int I Antimicrob Agents 26: 343-356. https://doi.org/10.1016/j.ijantimicag.2005.09.002

D'Adamo CR, Sahin A (2014) Soy foods and supplementation: a review of commonly perceived health benefits and risks. Altern Ther Health Med 20 (Suppl 1): 39-51

Franco OH, Chowdhury R, Troup J, Voortman T, Kunutsor S, Kavousi M, Oliver-Williams C, Muka T (2016) Use of plant-based therapies and menopausal symptoms: A systematic review and meta-analysis. IAMA 315: 2554-2563. doi: 10.1001/jama.2016.8012

Grynkiewicz G, Szeja W (2016) Synthetic glycosides and glycoconjugates of low molecular weight natural products. Curr Pharm Des 22: 1592-1627. doi: 10.2174/1381612822666151211094345

Huang J, Chen L, Xue B, Liu Q, Ou S, Wang Y, Peng X (2016) Different flavonoids can shape unique gut microbiota profile in vitro. $J$ Food Sci 81: H2273-H2279, doi: 10.1111/1750-3841.13411

Jensen KF (1993) The Escherichia coli "wild types" W3110 and MG1655 have $r p h$ frame shift mutation that leads to pyrimidine starvation due to low pyrE expression levels. J Bacteriol 175: 3401-3407. PMCID: PMC204738

Jędrak P, Sowa N, Barańska S, Węrzyn G (2017) Characterization of conditions and determination of practical tips for mtDNA level estimation in various human cells. Acta Biochim Pol 64: 699-704. doi: 10.18388/abp.2017_2303

Kim KH, Dodsworth C, Paras A, Burton BK (2013) High dose genistein aglycone therapy is safe in patients with mucopolysaccharidoses involving the central nervous system. Mol Genet Metab 109: 382-385. doi: 10.1016/j.ymgme.2013.06.012

Kim YM, Huh JS, Lim Y, Cho M (2015) Soy isoflavoneglycitin (4'-hydroxy-6-methoxyisoflavone-7-D-glucoside) promotes human dermal fibroblast cell proliferation and migration via TGF- $\beta$ signaling. Phytother Res 29: 757-769. doi: 10.1002/ptr.5313

Klein G, Żmijewski M, Krzewska J, Czeczatka M, Lipińska B (1998) Cloning and characterization of the $d n a K$ heat shock operon of the marine bacterium Vibrio harveyi. Mol Gen Genet 259: 179-189

Kloska A, Narajczyk M, Jakóbkiewicz-Banecka, Grynkiewicz G, Szeja W, Gabig-Cimińska M, Węgrzyn G (2012) Synthetic genistein derivatives as modulators of glycosaminoglycan storage. J Transl Med $\mathbf{1 0}$ : 153. doi: 10.1186/1479-5876-10-153
Kumar S, Pandey AK (2013) Chemistry and biologicalactivities of flavonoids: an overview. Sci World J 2013: 162750. http://dx.doi. org/10.1155/2013/162750

Marín L, Miguélez EM, Villar CJ, Lombó F (2015) Bioavailability of dietary polyphenols and gut microbiota metabolism: antimicrobial properties. Biomed Res Int 2015: 905215. doi: 10.1155/2015/905215

Mierziak J, Kostyn K, Kulma A (2014) Flavonoids as important molecules of plant interactions with the environment. Molecules 19: 16240-16265. doi: 10.3390/molecules191016240

Moskot M, Montefusco S, Jakóbkiewicz-Banecka J, Mozolewski P, Wegrzyn A, Di Bernardo D, Wegrzyn G, Medina DL, Ballabio A, Gabig-Cimińska M (2014) The phytoestrogen genistein modulateslysosomalmetabolism and transcriptionfactor EB (TFEB) activation. I Biol Chem 289: 17054-17069. doi: 10.1074/jbc.M114.555300

Moskot M, Jakóbkiewicz-Banecka J, Kloska A Smolińska E, Mozolewski P, Malinowska M, Rychłowski M, Banecki B, Wegrzyn G, Gabig-Cimińska M (2015a) Modulation of expression of genesinvolved in glycosaminoglycanmetabolism and lysosomebiogenesis by flavonoids. Sci Rep 5: 9378. doi: 10.1038/srep09378

Moskot M, Jakóbkiewicz-Banecka J, Smolińska E, Piotrowska E, Węrzyn G, Gabig-Cimińska M (2015b) Effects of flavonoids on expression of genes involved in cell cycle regulation and DNA replication in human fibroblasts. Mol Cell Biochem 407: 97-109. doi: 10.1007/s11010-015-2458-3

Moskot M, Gabig-Cimińska M, Jakóbkiewicz-Banecka J, Wesierska M, Bocheńska K, Węgrzyn G (2016) Cell cycle is disturbed in mucopolysaccharidosis type II fibroblasts, and can be improved by genistein. Gene 585: 100-103. doi: 10.1016/j.gene.2016.03.029

Mouradov A, Spangenberg G (2014) Flavonoids: a metabolic network mediating plants adaptation to their real estate. Front Plant Sci 5: 620. doi: 10.3389 / fpls.2014.00620

Peterson G (1995) Evaluation of the biochemical targets of genistein in tumor cells. J Nutr 125 (Suppl 3): 784S-789S. doi: 10.1093/jn/125. suppl_3.784S

Pierzynowska K, Gaffke L, Hać A, Mantej J, Niedziałek N, Brokowska J, Wegrzyn G (2018) Correction of Huntington's disease phenotype by genistein-induced autophagy in the cellular model. Neuromolecular Med 20: 112-123. doi: 10.1007/s12017-018-8482-1

Piotrowska E, Jakóbkiewicz-Banecka J, Wegrzyn G. (2010) Different amounts of isoflavones in various commercially available soy extracts in the light of gene expression-targeted isoflavone therapy Phytother Res 24: S109-S113. doi: 10.1002/ptr.2944

Sambrook J, Fritsch EF, Maniatis T (1989) Molecular Cloning: A Laboratory Manual (2nd edn). Cold Spring Harbor Laboratory Press, Cold Spring Harbor, New York, USA. https://trove.nla.gov.au/ version/45221481

Setchell KDR, Brown NM, Desai P, Zimmer-Nechemias L, Wolfe BE, Brashear W'T, Kirschner AS, Cassidy A, Heubi JE (2001) Bioavailability of pure isoflavones in healthy humans and analysis of commercial soy isoflavone supplements. J Nutr 131: S1362-S1375. doi: 10.1093/jn/131.4.1362S

Ulanowska K, Tkaczyk A, Konopa G, Węrrzyn (2006) Differential antibacterial activity of genistein arising from global inhibition of DNA, RNA and protein synthesis in some bacterial strains. Arch Microbiol 184: 271-278. doi: 10.1007/s00203-005-0063-7

Ulanowska K, Majchrzyk A, Moskot M, Jakóbkiewicz-Banecka J, Wegrzyn G (2007) Assessment of antibacterial effects of flavonoids by estimation of generation times in liquid bacterial cultures. Biologia 62: 132-135. doi: $10.2478 /$ s11756-007-0042-3

Wasilewski A, Krajewska U, Owczarek K, Lewandowska U, Fichna J (2017) Fatty acid amide hydrolase (FAAH) inhibitor PF-3845 reduces viability, migration and invasiveness of human colon adenocarcinoma Colo-205 cell line: an in vitro study. Acta Biochim Pol 64: 519-525. doi: 10.18388/abp.2017 1520

Wegrzyn G, Jakóbkiewicz-Banecka J, Gabig-Cimińska M, Piotrowska E, Narajczyk M, Kloska A, Malinowska M, Dziedzic D, Gołebiewska I, Moskot M, Wegrzyn A (2010) Genistein: a natural isoflavone with a potential for treatment of genetic diseases. Biochem Soc Trans 38: 695-701. doi: 10.1042/BST0380695

Wegrzyn A (2012) Gene expression-targeted isoflavone therapy. IUBMB Life 64: 307-315. doi: 10.1002/iub.1007

Xie Y, Yang W, Tang F, Chen X, Ren L (2015) Antibacterial activities of flavonoids: structure-activity relationship and mechanism. Curr Med Chem 22: 132-149. doi: 10.2174/0929867321666140916113443 